\title{
Investment and Innovation State Support of Agriculture in Russia as a Condition of WTO
}

\author{
Kuznetsov Vladimir V. \\ Russian Academy of Agricultural Sciences, Rostov on Don, Russia \\ Russian Research Institute of Economy and Regulations, Rostov on Don, Russia \\ Arkhipov Aleksey Y. \\ Southern Federal University, Rostov on Don, Russia \\ Soldatova Irina Y. \\ Russian Research Institute of Economy and Regulations, Rostov on Don, Russia
}

\begin{abstract}
Russian agriculture is one of the industries operating in the unstable economic situation in a developing market taking into account risks of the world economy, economic, political, and climatic factors. The role of agriculture is to provide people's needs for food, significant effects on employment, the efficiency of domestic production, and way of life in rural areas by obligatory preserving food security in Russia. One of the major tasks for agriculture is the development of innovations and investments aimed at improving the competitiveness of the domestic agricultural sector. Russia's membership in the WTO since 2012 is getting a particular importance in the innovation and investment support of agriculture. The strategy of innovative development of the Russian Federation until 2020 “Innovative Russia-2020” assumes three possible options for innovative development: inertial (directed on imports), catch-up development and a local technological competitiveness and a variant of achieving leadership in leading scientific and technical sectors, and fundamental research. A positive point is that the strategy provides an algorithm of state support of the innovation cycle. The innovation cycle is the process associated with the sequence of innovation transformations (scientific or business ideas) in products, technology, business process and launches it on the market for commercial use. A positively developing regional aspect is of great importance.
\end{abstract}

Keywords: Russian agricultural sector, investment and innovation policy, agriculture in the Rostov region, the entry into the WTO agriculture

\section{Investment Climate in the Russian Agriculture}

Over the last few years in agriculture there has been a positive change, caused by the fact that, firstly, thanks to government regulation and increased support for the sector direct, investments are getting more

Kuznetsov Vladimir V., Doctor of Economics, Professor, Academician of Russian Academy of Agricultural Sciences; Chief Scientific Officer of Russian Research Institute of Economy and Regulations.

Arkhipov Aleksey Y., Doctor of Economics, Professor, Director of the Institute of Economy and Foreign Economic Relations, Southern Federal University.

Soldatova Irina Y., Doctor of Economics, Professor, Chief Scientific Officer of Russian Research Institute of Economy and Regulations.

Correspondence concerning this article should be addressed to Soldatova Irina Y., 344022, Rostov on Don, Kirovskiy 44, fl. 90 , Russia.E-mail: sold@aaanet.ru. 
attractive. Secondly, investors have become sensitive to the agricultural industry due to the rise in world food prices and the increasing importance of agriculture as a whole. Prime Minister Medvedev talked about the need for Russia's economy to diversify from a raw-material dependent economy to an innovation-based economy. Russia has developed a strategy of innovative development of the Russian Federation until 2020 "Innovative Russia - 2020” (The Ministry of Economic Development of the Russian Federation, 2011), the implementation of which will significantly increase innovation and investment in the agricultural and industrial sector.

At present, the agriculture of the country is about $8.5 \%$ of gross domestic products, the industry is concentrated $3.4 \%$ of fixed assets. Agriculture employs more than 7.3 million people. In addition, Russia has one of the greatest world's economic potentials for the production of agricultural products: $8.9 \%$ of the global arable land; $2.6 \%$ of pasture; and 20\% of the world's water. In 2008-2013 the need for investment in this sector is $\$ 70$ billion (Denisov, 2010).

In the changing situation in agriculture, an important role was played by the national project "Development of Agriculture", carried out in 2006 and 2007, which gave a powerful stimulus to the development of agriculture, i.e., it became apparent that the agricultural sector is a promising sector of the economy that needs investment. In the implementation of the national project "Development of Agriculture" and the State Agricultural Development Programme and regulation of the market of agricultural products, raw materials and food for 2008-2012 appropriations for the support and development priorities of the agricultural sector were significantly increased, the investment process was activated. If in 2005, the total amount of loans involved in agriculture amounted to about 192 billion rubles, in 2007 it was already attracting 432.6 billion rubles. The volume of direct investment loans rose during the same period from 26 billion to 138.5 billion rubles. In 2009, 48 billion and 40 billion rubles were directed to finance investment projects in beef and dairy cattle. In 2010, the priorities of making investments are: dairy and meat animal breeding, poultry, modernization of the sugar mills, primary processing and grain storage, and primary processing of milk and meat. By sectors of agriculture, the share of own funds accounted for $30 \%$ of the investment, they are a major source of investment finance.

A massive inflow of investment is possible only in the case of investors' confidence in the federal and regional authorities understanding the need for a targeted investment policy that is linked to an adequate legal framework, and taking serious steps to improve the investment climate and the increased inflow of foreign (mainly direct) investments in the real sector of the economy through the expansion of benefits and guarantees.

Seven hundred and seventy-six billion credit resources were attracted to the agricultural and industrial sector in 2009, lending growth for the year was approximately 9\%. Two major banks that lend to agriculture are Agricultural Bank and Sberbank of Russia. Agricultural Bank increased its lending to agricultural and industrial sector by $33 \%$, Sberbank-by $10 \%$. The total amount of the federal budget for the implementation of the state program of agricultural development in 2011 was 149.7 billion rubles, 97.9 billion rubles of them will go directly to agricultural producers to support the production and social development of rural areas.

Significant amount of funds is to be spent on maintenance of investment credits -59.8 billion rubles, or $76 \%$ billion rubles. The part of the grant will be allocated to new investment projects. The priority areas of investments are dairy and meat and poultry, as well as processing and storage of grain. More than half (54\%) of credits will be allocated to livestock. The analysis of the forms of state support is presented in Table 1 . 
Table 1

Forms of Government Support for Agriculture

\begin{tabular}{|c|c|c|}
\hline Direct & Indirect & Mediated \\
\hline $\begin{array}{l}\text { (1) Subsidies on agricultural production } \\
\text { and logistics resources, interest rate } \\
\text { subsidies on loans; } \\
\text { (2) Subsidies to compensate for part of } \\
\text { the costs of agricultural producers; } \\
\text { (3) Grants for capital expenditure, etc.. }\end{array}$ & $\begin{array}{l}\text { (1) Preferential taxation; } \\
\text { (2) Purchases of agricultural products } \\
\text { and foodstuffs for public use; } \\
\text { (3) Procurement and trade interventions } \\
\text { with grain; } \\
\text { (4) Protection of the economic interests } \\
\text { of producers in foreign trade activities, } \\
\text { etc.. }\end{array}$ & $\begin{array}{l}\text { (1) The implementation of the various } \\
\text { programs that are not directly related to } \\
\text { the agricultural industry; } \\
\text { (2) Participation in the activities of trade } \\
\text { associations; } \\
\text { (3) The implementation of regional } \\
\text { programmes of mechanical engineering; } \\
\text { (4) Implementation of training } \\
\text { programmes and retain young } \\
\text { professionals in the agricultural areas, } \\
\text { etc.. }\end{array}$ \\
\hline
\end{tabular}

\section{Agriculture in Russia in Terms of Joining the WTO}

The Russian Federation officially became a full 156th member of the World Trade Organization (WTO) on August 22, 2012 (Protocol on Russia's entry to the Marrakesh Agreement on Establishing the World Trade Organization (WTO), 2012).

Russia's WTO membership creates for agrarian business fundamentally new norms and regulations, a new organizational and economic, legal environment of operation. These are:

- Increase of efficiency of agricultural production (access to cheaper components and raw materials, new technologies of agricultural and industrial complex);

- Increase in the share of agricultural exports for individual headings in total (the production of organic foods, etc.);

- Introduction of common standards in the world;

- Maintaining adequate protection of domestic producers in a reasonably open economy;

- Development of international cooperation in the production of agricultural products, food and agricultural trade.

With Russia's joining of the WTO, it became necessary to make a transition for enterprises to international quality standards. To reduce competition from importers' side, more attention should be paid to the technological processes of growing, processing, and storage of agricultural products. The quality and safety of food products depend on the technical level of production, used technologies, and staff skills. Significant depreciation of fixed assets and the lack of modern equipment do not allow many companies to process fully agricultural raw materials and apply modern waste technologies.

WTO membership, the influential international organization, will give an opportunity to provide the favorable, stable, and non-discriminatory access conditions for Russian exporters of goods and services to foreign markets; provide reasonable protection of domestic producers in an open economy; predictability, uniformity of the legal environment of foreign economic activity; influence the formation of multilateral trade rules taking into account Russian national interests.

Director of the Eurasian Centre for Food Safety, a professor of Lomonosov Moscow State University, a member of the negotiations on Russia's joining the WTO-Sergey Kiselev says that after Russia joins the WTO, and weakness in this regard of the import regime of products of agricultural and food industry, the 
supply of these products in our country will increase by almost \$200 million. According to Kiselev, after joining WTO, the import of agricultural products to Russia will increase by $0.6 \%-0.7 \%$ (11.9 million), the import of food products will increase by 2.3\%-2.4\% (182-190 million dollars). At the same time the level of customs protection of the grain market will be reduced by $30.5 \%$ (end-binding of $14.9 \%$ ), its products—by 26.1\% (10.5\%), and sugar and confectionery products—by 28.5\% (11.8\%) (Kisilev, 2012).

In connection with the participation of Russia in the WTO, the classification of state support of the agrarian sector of the economy adopted by the European Union is of special interest. In accordance with the Agreement on Agriculture, internal measures of state support for agriculture are classified into four categories- "baskets" (see Table 2). For Russia, the form of state support of "green basket", the main measures of which are crop insurance, development of consulting, and information support of rural producers is of a particular interest.

Table 2

Measures of State Support of Agriculture

\begin{tabular}{|c|c|c|c|}
\hline No. & $\begin{array}{l}\text { Forms of state } \\
\text { support }\end{array}$ & Types of state support & Possibilities of use in Russia \\
\hline 1. & $\begin{array}{l}\text { Measures of } \\
\text { "blue basket" }\end{array}$ & $\begin{array}{l}\text { State payments aimed at limiting the size of agricultural land and reducing } \\
\text { the number of livestock; monetary compensation provided to farmers in the } \\
\text { event of voluntary reduction in their production volume. }\end{array}$ & $\begin{array}{l}\text { Absent due to ongoing } \\
\text { systemic crisis in the } \\
\text { agrarian economy. }\end{array}$ \\
\hline 2. & $\begin{array}{l}\text { Measures of } \\
\text { "green basket" }\end{array}$ & $\begin{array}{l}\text { Financial expenses of the state which have no direct impact on the increase } \\
\text { of production and terms of trade: the cost of crop insurance, consulting } \\
\text { development in rural areas and information support of rural producers, } \\
\text { improving of rural infrastructure, conducting research, etc.. }\end{array}$ & $\begin{array}{l}\text { Applicable } \\
\text { conditions. }\end{array}$ \\
\hline 3. & $\begin{array}{l}\text { Measures of } \\
\text { "yellow basket” }\end{array}$ & $\begin{array}{l}\text { All expenses of the state to support the agriculture are not included in the } \\
\text { "blue" and "green" basket (indicator: aggregate measures of support). }\end{array}$ & $\begin{array}{l}\text { Reasonable to be used to } \\
\text { stimulate the production. }\end{array}$ \\
\hline 4. & $\begin{array}{lr}\text { Measures } & \text { of } \\
\text { “special } & \text { and } \\
\text { differential } & \\
\text { treatment” } & \end{array}$ & $\begin{array}{l}\text { Investment grants and subsidies for the purchase of materials and } \\
\text { equipment. }\end{array}$ & $\begin{array}{l}\text { Provided } \quad \text { only } \\
\text { developing countries. }\end{array}$ \\
\hline
\end{tabular}

Possible investment and innovation positive goals of Russia's joining the WTO are:

- Creating a more favorable climate for foreign investment as a result of bringing the legal system into conformity with the WTO rules;

- Increased opportunities for Russian investors in the countries - the WTO members;

- Increase of the investment attractiveness of the Russian economy;

- Russia as a member state will be able to participate in the formulation of the rules of international trade and investment, as well as to protect its trade interests using the existing WTO dispute-settlement system;

- Better than the existing, non-discriminatory conditions for access of Russian goods to foreign markets;

- An international mechanism for resolving trade disputes;

- Creating the conditions for improving the quality and competitiveness of domestic production by increasing the flow of foreign goods, services, and investments in the Russian market;

- Participation in the development of international trade rules taking into account national interests;

- Improving of Russia's image in the world as a full participant in international trade;

- The expansion of world trade, increasing competitiveness of Russian companies;

- Increased attention and responsibility in respect to the intellectual property rights of Russian 
manufacturers and consumer rights;

- Simplifying and rationalizing of procedures for conformity of products with international standards;

- Costing reduction and elimination of duplication of supervision and controlling over compliance with the quality of agricultural products.

In the long term, the system of management of foreign economic relations will become more stable. Businessmen for years to come will know what duty is established, at which point it will be applied.

In the short term, problems may appear for individual companies which are non-competitive at present time. Other factors, such as changes in exchange rates, the state of the world economic situation, investment activity will affect the Russian economy to a much greater extent. In the long term, factor of Russia's participation in the WTO will provide unconditional positive impact on economic growth in Russia, promoting trade and investment, increasing competitiveness in the domestic market, and creating a clear international legal framework for domestic policy in the sphere of regulating foreign trade.

According to the World Bank consultant David Tarr, Russia benefits from the implementation of total liabilities after joining the WTO in the medium term (within three years of the entry) will be around 3.3\% of GDP growth annually. It is about 49 billion dollars, based on 2010 data, he said. In the long term (10 years), the annual growth could reach 11\% of GDP (162 billion dollars) (Tarr, 2012).

Russia's losses from WTO membership, with negative scenarios, are as follow:

- The weakening of national sovereignty because of competitiveness;

- Many businesses cannot compete with the influx of foreign goods and services are often cheaper and more qualitative, may cut jobs;

- The cost of competitive Russian products will increase;

- Additional inflation and a loss of competitiveness in the world market of power-intensive industries (manufacturing industry);

- WTO Agreement prohibits member states providing government subsidies, restrictions relate mainly to export subsidies in the industry, which are practically not applied in Russia, or subsidies for import substitution.

\section{Regional Support for Agriculture in Russia (on the Example of the Rostov Region)}

Russian regions in recent years pay more attention to agriculture. Thus, in the Rostov region in 2010, the volume of investments (from all sources) for large- and medium-sized enterprises amounted to 11.4 billion rubles, it is 2.5 times more than that in 2005. Investment in agriculture, hunting, and forestry is 7.2 billion (or 2.4 times more than that in 2005), in the manufacture of food products, beverages, and tobacco-4.2 billion (Retrieved from http://www.don-agro.ru). For the first half of 2011, the volume of investment in fixed capital in agriculture, hunting, and forestry is 3.7 billion, food production is 1.2 billion (see Figure 1).

In recent years in the Rostov region a number of laws and regulations were passed that provide incentives for investors of agricultural and industrial sector. Regional Law of 01.10.2004 No. 151-ES "On investments in the Rostov region" establishes tax incentives for corporate income tax and business property tax to investors carrying out investment activities in the region: the establishment of the tax rate on property tax organizations of $1.1 \%$, to establish tax rates on corporate income tax at a rate of $13.5 \%$ in the amounts payable to the regional budget. 


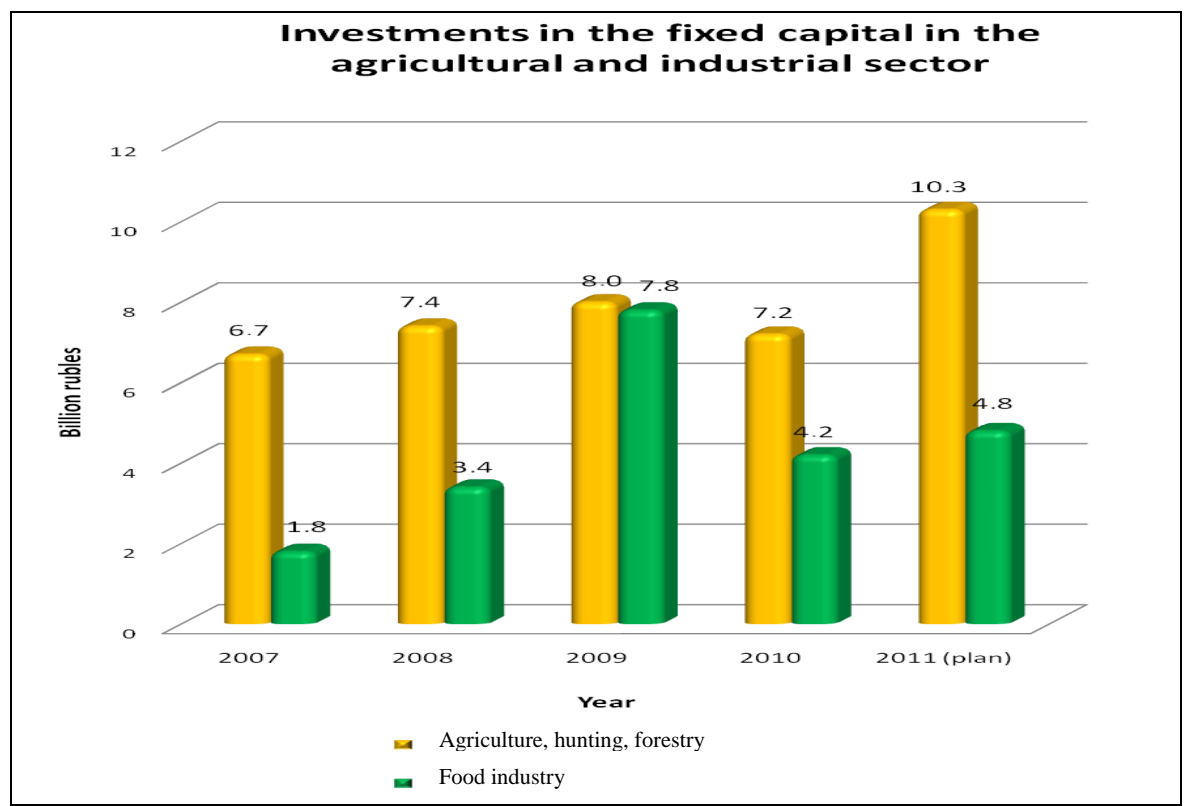

Figure 1. Investments in the fixed capital in the agricultural and industrial sector.

On July 1, 2011, businesses and organizations are planned in the framework of the investment project creation (acquisition) of property investments with a volume of 300 million rubles or more are exempt from paying taxes on the newly created (acquired) property, as well as they have an opportunity to apply the reduction factors when determining the amount of rent for the use provided for the construction of land, state ownership is not well defined, either in the public domain of the Rostov region (validity of benefits-for the construction period, but not more than five years).

Regional Law of 04.10.2000, No. 106-ES “on the investment tax credit in the Rostov region" sets the conditions providing investors with tax credits for corporate income tax and regional tax in terms of coming into the regional budget. The subsidizing interest rates on investment loans are put into practice. Thus, of the 1.4 billion or $70 \%$ of the allocated funds are spent to subsidize the loans taken for the construction of facilities for the production and processing of meat and 242.2 million (30\%) for technical and technological modernization of agriculture ${ }^{1}$.

On December 2010, at the Council for Investments at the Head of the Administration (Governor) of the Rostov region, it was decided to create a list of the "100 Governor's Investment Projects", which is based on the most economically and socially important investment projects. As a result of selection in the "Governor Hundred”, there included 24 long-term investment projects of agriculture.

\footnotetext{
${ }^{1}$ Order of the Ministry of Agriculture of the Russian Federation from 27.07.2011, No. 241 "On the Procedure for the selection of investment projects"; Resolution of the Government of the Rostov region of 20.01.2012, No. 58 "on the procedure for granting subsidies to partially compensate the interest on loans received from Russian credit institutions and loans received in agricultural credit consumer cooperatives"; Resolution of the Government of the Rostov region of 20.01.2012, No. 26 "on the order of subsidies from the regional budget for the reimbursement of expenses for lease payments"; Resolution of the Administration of Rostov region from 05.09.2008, No. 449 “on some issues of state guarantees of Rostov region”; Regional Law of the Rostov region of 22.07.2010, No. 448-ES “on the basis of public-private partnership"; Resolution of the Government of the Rostov region of 27.02.2012, No. 128 "on the Procedure for participation by a public-private partnership in the implementation of the investment project in the Rostov region”; Order of the Ministry of Agriculture and Food of the Rostov region of 26.01.2012, No. 10 “on the determination of the amount of subsidies from the regional budget for reimbursement of the cost of interest on investment loans (credits); Investment potential of the agricultural sector of the Rostov region. The Ministry of Agriculture and Food of the Rostov region, Rostov on Don (Retrieved from http://www.don-agro.ru).
} 


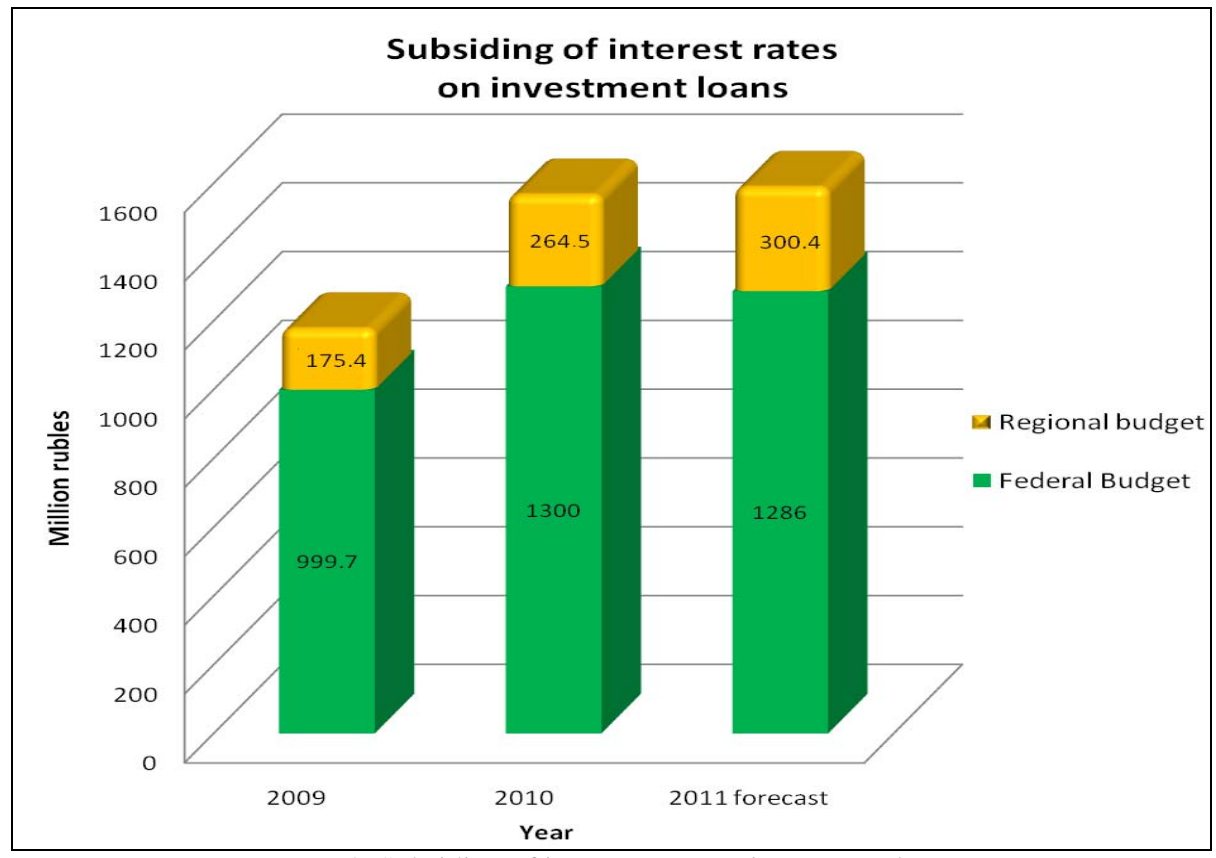

Figure 2. Subsiding of interest rates on investment loans

The total investment on projects in the field of agriculture and industrial sector included in the "Governor Hundred” is 85.4 billion rubles. As a result of their implementation, it is planned to create $16,100,000$ jobs. In view of Russia's joining the WTO, the forms of agricultural support including the regions will be adjusted in accordance with the requirements of this international organization. However, the permitted forms of support will not only be maintained, but also grow.

\section{Conclusions and Recommendations}

(1) Russia's entry to the WTO is a final factor in the formation of a new geopolitical status of Russia as an important part of the modern globalized world economy. This status presupposes the active participation of the country's agriculture in the international economic interaction. Entry of the Russian agriculture into the world market requires the following:

- The state should work out a series of measures to protect the Russian agriculture in the global competition;

- It will take time to make the changes in the Russian legal system, a system of quality control and pricing;

- Agricultural and industrial sector must necessarily be supported by the state while ensuring food security;

- It is necessary to provide the regional support for agricultural and industrial sector when entering the global market.

The task for Russia is not so much integration into the world market as integrated into modern institutions of international regulation. WTO membership will create favorable conditions for the establishment and expansion of new sectors of the economy. The foreign doctrine of Russia should be targeted at a post-industrial breakthrough, rather than a primitive defense of "domestic producers". That is why the entry to the WTO can and should be a major factor in the modernization and innovative development of Russia.

(2) Russian agriculture is one of the industries operating in an unstable world and national economic environment of developing markets. The importance of agriculture is to ensure the population's needs for food, it greatly affects employment, the efficiency of domestic production, and way of life in rural areas. 
Undoubtedly, food security in Russia, in the world economy, depends on how the production and activity in agriculture is operating. Therefore, one of the major challenges for agriculture today, especially with the entry into the WTO, is to create a market for innovation and investment, aimed at the issues of self-financing and the competitiveness of the domestic agricultural sector, taking into account food security.

Firstly, investment and innovation have specific features in the agricultural and industrial sector: the seasonal nature and the relatively long cycle of agricultural production, the price disparity for a purchased industrial and sold agricultural products, a significant amount of capital expenditure for land reclamation and improvement of land, which increases the cost of production and reduces the return on investment.

Secondly, farming without government support is an unprofitable sector. This industry exists because of subsidies and is characterized by extremely long investment cycle. The attraction of direct investments is growing thanks to government regulation and support for the sector, investors started treating agricultural industry differently due to the rise in world food prices and the increasing importance of agriculture as a whole.

(3) Because of Russia's entry to the WTO, the global agricultural market assumes a substantial state support of domestic producers. The WTO is a prerequisite for admission to the Organization for Economic Cooperation and Development (OECD), and in the future-for the shaping of common European economic space. The first priority for Russia is not so much integration into the world market as integrated into modern institutions of international regulation. WTO membership will create favorable conditions for the establishment and expansion of new sectors of the economy, including agriculture.

(4) The strategy of investment and innovation development of agriculture and agricultural organizations is based on several basic principles: active government support; a combination of methods and tools market and state regulation of investment processes; validity of priority agricultural and industrial sector development; innovations; development and improvement of information and consultation activities; and improving of the competitive system assessment and selection of innovative projects and programmes.

(5) The Russian Federation and regions have considerable potential for the development of agriculture on the basis of investment and innovation. Innovative mechanisms improve the efficiency of investment projects, shortening their payback and significantly influencing the competitiveness of products. In each project, the innovative component must be carefully worked out, taking into account the totality of factors that allow the economy to simulate the period when the project will be basically implemented. Modern economic and mathematical methods provide the prepared projects with a high quality.

\section{References}

Denisov, V. (2010). Investments in agriculture: Playing in a foreign field. Business Newspaper.

Jim Y. K. (2013). What’s next for Russia’s economic future and global role?. Russian Presidential Academy of National Economy and Public Administration, Moscow, Russian Federation.

Kisilev, S. (2012). Sight: Business newspaper. Protecting indirectly.

Partnership Strategy (CPS), the International Bank for Reconstruction and Development, the International Finance Corporation and the Multilateral Investment Guarantee Agency and the Russian Federation for 2012-2016. (2011). Report Number 65115-RU. Retrieved from http://www.CPSrus12192011clean.pdf

Protocol on Russia's Entry to the Marrakesh Agreement on Establishing the World Trade Organization (WTO). (2012). Retrieved from http://www.wto.org/english/res_e/booksp_e/analytic_index_e/wto_agree_03_e.htm

Serova, E., \& Charles, N. (2012). Analytical centre, APE, the agreement on agriculture uruguay round of the GATT and the impact of Russia's entry to the WTO on agricultural and food sector. Retrieved from http://www.gatts-wto-and-agriculture-chapter_rus 
Tarr, D. (2012). Sight: Business newspaper. Protecting indirectly.

The Ministry of Economic Development of the Russian Federation. (2011). The strategy of innovative development of the Russian Federation “Innovative Russia-2020” (Official Government policy document, Moscow).

The World Bank. (2009). Implementing agriculture for development. Retrieved from http://www.agriculture_Action_Plan_web The World Bank. (2012). Agricultural innovation systems: An investment source book. Washington, D.C.: The World Bank. 